УДК: 025.4.021

Савченко Зоя В'ячеславівна, науковий співробітник Інституту інформаційних технологій і засобів навчання НАПН України, м. Київ

\title{
КОЛЕКЦІЇ ЕЛЕКТРОННИХ ІНФОРМАЦІЙНИХ РЕСУРСІВ І ЇХ МЕТАОПИСИ ЯК КОМПОНЕНТИ НАУКОВИХ ЕЛЕКТРОННИХ БІБЛІОТЕК
}

Анотація

У статті подано результати дослідження складових наукових електронних бібліотек, основними 3 яких $€$ колекції наукових електронних інформаційних ресурсів. Наведено найважливіші специфічні особливості колекцій наукових інформаційних ресурсів, джерела їх формування, структуру колекцій, методи їх систематизації, технології створення, забезпечення підтримки та використання наукових колекцій; роль і функції метаданих у колекціях і технології управління метаданими. На етапі проектування й упровадження наукових електронних бібліотек можуть бути використані результати дослідження, наведенні в статті, а саме: схема формування колекцій наукових інформаційних ресурсів; етапи проектування i розробки метаописів i використання стандарту Дублінське ядро, створення метаописів.

Ключові слова: колекції електронних інформаційних ресурсів, електронна бібліотека, метадані, метаописи.

Актуальність проблем, висвітлених у статті, визначається важливістю створення електронних бібліотек (ЕБ) та колекцій інформаційних ресурсів (IP), що сприяє формуванню ефективної інфраструктури і доступу до єдиного інформаційного науково-освітнього простору. Завдяки використанню новітніх електронноінформаційних технологій у бібліотечній справі, такий доступ забезпечує якісно новий рівень задоволення інформаційних потреб спільноти науковців та зацікавлених верств користувачів, сприяє підтримці наукових досліджень та ефективнішому використанню наукових електронних інформаційних ресурсів (HEIP), позитивно впливає на розвиток науки, техніки, культури і дозволить поліпшувати систему освіти, підвищувати ефективність і якість навчання, творчу діяльність студентів як майбутніх освітян і науковців. 
Метою статті $є$ висвітлити результати досліджень і опрацювання джерел літератури й Інтернет ресурсів щодо колекцій HEIP та метаданих їх опису як основних компонентів ЕБ. А також розробити відповідні рекомендації за результатами досліджень щодо особливостей наукових колекцій, джерел формування, структури таких колекцій, методів їх систематизації, технології форматного забезпечення формування та управління метаданими, які можна використати під час створення наукової ЕБ НАПН України.

Об'єктом дослідження $\epsilon$ процес формування i використання колекцій електронних інформаційних ресурсів науковими установами НАПН України.

Предмет дослідження становлять теоретичні i методичні положення 3 формування колекцій ЕIP і використання їх у науково-освітньому просторі.

У цьому дослідженні використано загальнонаукові методи системного підходу, аналізу і синтезу під час визначення й узагальнення принципів формування колекцій HEIP та використання їх.

Вступ. Одним із важливих напрямів, які активно розвиваються останніми роками, є розробка інформаційних систем нового класу наукових електронних бібліотек та створення колекцій інформаційних ресурсів. Науковим фондом ЕБ $є$ сукупність електронних колекцій за науковою спрямованістю діяльності наукових установ. Електронний інформаційний фонд наукових бібліотек складається з ЕІР, які створюються як сукупність баз даних електронних тематичних колекцій, бази даних порталу, електронних каталогів. Такий електронний фонд ЕБ створюється для забезпечення якісно нового рівня задоволення інформаційних потреб спільноти науковців у науково-освітньому середовищі, можливостей удосконалення методів роботи в проведенні наукових досліджень, здобутті знань в освіті, що вимагають достовірної, своєчасної і повної інформації, яку можна отримати завдяки використанню новітніх інформаційно-комунікаційних технологій (ІКТ) у бібліотечній справі.

Нагальність створення електронних колекцій бібліотек зумовлюється кількома чинниками: стрімким розвитком IКТ, збільшенням кількості документів, що існують лише в електронному вигляді, систематизації та каталогізації цих ресурсів для якнайшвидшого та якісного забезпечення користувачів у всезростаючих потребах у віддаленому доступі до інформаційних носіїв, зміцненням практики науковців, 
студентів і учнів працювати тільки з електронними варіантами документів i, нарешті, власним прагненням наукових ЕБ надавати користувачам інформаційні послуги підвищеної якості та пропагувати актуальні новітні досягнення в галузі наукових доробок та досліджень.

Огляд електронних колекцій, що доступні в Інтернеті, дозволяє зробити певні висновки щодо тенденцій розвитку цього напряму бібліотечної діяльності.

Найефективнішою є консорціумна модель створення ЕБ. Як приклад можна навести досвід спеціалізованого інформаційного продукту РФ агенції з науки й інновацій - Наукову електронну бібліотеку, у якій збирається й обробляється повна бібліографічна інформація про журнальні статті, анотації та пристатейні списки літератури, що цитується у статтях (http://www.elibrary.ru/). Успішно розвивається такий вид електронних колекцій, як відкриті архіви: архів наукової інформації ArXiv, що надає відкритий доступ до 426 тис. наукових видань 3 фізики, математики, комп'ютерних наук та біології; проект Корнельського університету (США), що пропонує систему архівування та обміну препринтами (http://www.arxiv.org/); проект Dspace - система відкритого доступу до наукової інформації, розроблена бібліотекою Масачусетського технологічного інституту та корпорацією Неwlett Packard (http://www.dspace.org/). Ця база даних надає безкоштовний доступ до електронних документів таких типів: статей i препринтів, технічних звітів, напрацювань конференцій, дисертацій, навчально-освітніх матеріалів, статистичних даних та ін.

Вітчизняним прикладом потужного електронного продукту $є$ електронний фонд Національної бібліотеки України ім. Вернадського (http://www.nbuv.gov.ua/eb/ep.html).

Колекції є найпоширенішою формою організації електронних інформаційних ресурсів у ЕБ [1]. Під час розробки колекцій IP з природничо-наукових досліджень (наприклад, з механіки, теоретичної фізики), інколи застосовується підхід, коли для однієї й тієї ж колекції співіснує декілька концептуалізацій предметної галузі, відповідно до різних теорій і моделей досліджуваного феномену. Це дозволяє, зокрема, по-різному інтерпретувати дані одних і тих же експериментів. Для наукових колекцій IP не є незвичайною неповнота чи нечіткість відомостей, що подаються 
ними. Окрім того, сама концептуалізація предметної галузі дослідження, покладена в основу колекції, може мати гіпотетичний характер.

Слід зазначити, що в багатьох галузях наукових досліджень [1] застосовуються бібліографічні колекції, а також колекції повнотекстових наукових публікацій. Значний ефект може дати інтеграція колекцій цих двох видів. За результатами пошуку в бібліографії користувач може, не перериваючи сеансу роботи з пошуковим сервісом, дістати доступ до анотацій і повних текстів знайдених робіт, що містяться в наукових електронних бібліотеках, а також низці видавництв, якщо користувач має відповідні необхідні повноваження.

Наукові колекції значимі, перш за все, за використанням їх широким колом користувачів як науковців, викладачів ВН3, учителів, студентів та учнів. Існують як персональні колекції окремих учених i колекції колективів дослідницьких лабораторій, так і колекції, що мають національне або світове значення і надаються для глобального доступу. Варто зазначити, що ці характеристики колекції можуть змінюватися з часом. Персональна колекція вченого може з часом мати високий рівень значущості для багатьох учених, і з оглядом на це потрібно буде забезпечити до неї ширший доступ науковців [2].

Порівняно 3 великомасштабними колекціями персональні та лабораторні наукові колекції можуть мати відносно короткий термін існування, зазвичай, вони динамічніші за структурою i складом HEIP. Інформаційні потреби науковцівдослідників взагалі значно динамічніші порівняно, наприклад, з відносно стабільними потребами управлінських працівників, діяльність яких значною мірою регламентована. Тому в наукових ЕБ повинні передбачатися досить гнучкі призначені для користувача інтерфейси, здатні адаптуватися до зміни потреб користувачів. Ця обставина повинна враховуватися при організації наукових колекцій. На відміну від HEIP інших видів колекцій, у наукових колекціях можуть бути подані відомості не про реальні процеси і явища, а гіпотетичні дані, або дані дослідницьких експериментів з гіпотетичними дослідницькими моделями. Достовірність відомостей, що містяться в HEIP колекції, може бути забезпечена лише відносно досягнутого рівня знань 3 даної галузі науки. Вона може бути спростована в процесі подальших досліджень. У наукових колекціях можуть міститися альтернативні (можливо, навіть суперечливі) відомості про досліджувані об'єкти, явища або процеси. У таких 
ситуаціях, зазвичай, неправомірно вести мову про інтегральну цілісність даних у колекції.

Основна частина. Як уже зазначалося, колекції є найпоширенішою формою організації електронних інформаційних ресурсів під час створення і формування ЕБ. 3 огляду на широкі можливості наявних ІКТ і різноманітну природу інформаційних ресурсів, характеристики цих колекцій дуже різноманітні. Проте колекції мають i деякі загальні властивості, розуміння яких має істотне значення для розробки ЕБ.

Тематична спрямованість електронних колекцій визначається напрямками діяльності установ, які створюють HEIP. Електронні тематичні колекції мають у своєму складі електронні документи і посилання на адреси мережевих електронних інформаційних джерел [3].

Процес створення електронних колекцій має кілька аспектів діяльності:

- створення електронних IP;

- керування електронними фондами;

- $\quad$ пошук повнотекстових електронних ресурсів;

- $\quad$ надання доступу до електронних ресурсів.

3 опрацювань літератури [1-3] зазначеної тематики досліджено, що електронна колекція - це систематизована сукупність HЕIP, які об'єднані за певними критеріями чи загальними властивостями: наприклад, за подібністю тематики, джерелами наповнення, цілями призначення, за колом користувачів або способом доступу. Критерієм може бути будь-яка властивість електронного IP або їхня ієрархічна структура. Областю визначення критерію часто розглядається набір елементів опису IP DUBLIN Core, який останнім часом набуває статусу стандарту, розширений певними елементами: наприклад, користувач, власник, призначення, цінність, стандартні класифікатори та рубрикатори ББК, УДК, ГРНТИ, класифікатор BAK [2].

Поряд із систематизацією HEIP [1], за якою організовуються колекції, до важливих властивостей $i$ характеристик колекцій інформаційних ресурсів відносяться:

- призначення колекції НЕIP, характеристики генезису;

- види базових інформаційних технологій, що використовуються;

- способи подання складу НЕІР і правила опису їх; 
- характеристики представлення HEIP (середовище подання - текст, графіка, формати, способи кодування та ін.);

- $\quad$ однорідність/неоднорідність HEIP (у різних аспектах), зосередженість /розподілення їх, характеристики обсягу IP;

- ступінь динамічності складу колекції і стану ресурсів, ступінь повноти колекції;

- оцінка несуперечності IP, характеристика соціальної важливості колекції;

- $\quad$ способи доступу користувачів до колекції НЕIP та ін.

Коротко висвітлимо деякі $з$ перерахованих властивостей.

Можливі різні підходи до подання складу колекції [4]. У простому випадку колекція подається явно - безпосередньо як сукупність НЕIP, що належать їй, або як список посилань на них (наприклад, URL/URI ресурсів WWW). Інший підхід передбачає неявне подання складу HEIP шляхом специфікації критеріїв належності цих ресурсів даній колекції (Membership Criteria). Такий підхід можна використовувати в колекціях, що формуються на основі глобального розподіленого гіпертекстового середовища WWW. Ще одним прикладом його використання $\epsilon$ створення колекції, що формується на основі повнотекстової документальної системи шляхом специфікації пошукового запиту. Склад HEIP неявно заданих колекцій динамічний і в кожен момент часу залежить від стану інформаційного простору джерела колекції. Колекції подібного роду називають динамічними. За такого підходу створення колекцій, для їх «матеріалізації» необхідний спеціальний сервіс для пошуку і вибірки ресурсів, що до неї належать.

На практиці часто використовуються також колекції, склад і види HЕIP яких незмінні, або ж змінюються не дуже часто (статичні колекції). Такі колекції мають важливу властивістю - тиражування. Прикладами статичних тематичних колекцій гіпермедійних IP є багато популярних Web-сайтів. Широко практиковане у WWW створення «дзеркальних» сайтів має сенс саме у зв'язку із статичним характером сайтів-джерел.

\section{Систематизація НЕIP колекції за іменами}

У багатьох розробках одним 3 елементів систематизації подається єдина система іменування EIP, що належать до колекції. Вибір ефективних правил іменування IP є істотним, особливо для великих колекцій. Лаконічні імена, які легко 
асоціюються 3 функціональними назвами ресурсів колекції, істотно спрощують роботу користувачів. Надані ресурсам імена мають бути унікальними в рамках колекції в цілому, або деяких підмножин іiі НЕIP. Інколи на ім'я ресурсу покладається функція ідентифікації його (логічного) місця в колекції в рамках прийнятої систематизації.

Природа і середовище представлення колекцій НЕIP можуть бути різними. Це можуть бути наукові звіти, монографії, результати спостережень природних феноменів, дані комп'ютерних модельних експериментів або приладових вимірів, географічні карти і тому подібне. IP можуть бути представлені в будь-якому моносередовищі: тексти, зображення, аудіо або відео чи мультимедійними. Організація і способи представлення HEIP колекції, у тому числі і метаданих, істотно залежать від інформаційних технологій, які використовуються в даній ЕБ.

\section{Систематизація НЕIР колекції за тематикою предметної галузі}

Систематизація колекції здійснюється, як правило, на основі властивостей предметної галузі (ПГ) колекції i/або властивостей іiі IP i їхніх користувачів, характеристик процесу формування колекції i/aбо учасників цього процесу, за хронологічним принципом i т. д. Систематизація колекції 3 використанням властивостей іï ПГ повинна грунтуватися на концептуалізації цієї ПГ. Побудована в результаті вивчення й аналізу ПГ концептуальна модель може в той же час використовуватися для забезпечення й оцінювання повноти вмісту колекції. Концептуальна модель ПГ може мати різні форми представлення.

У процесі формування колекції необхідно вирішити такі основні завдання:

- визначення змістового складу колекції;

- $\quad$ визначення джерел їх формування ;

- принципів систематизації колекції;

- забезпечення повноти і несуперечності IP;

- $\quad$ вибір відповідних інформаційних технологій для формування, підтримки і використання колекції.

Завдання, пов'язані 3 визначенням складу колекції, систематизацією та забезпеченням повноти колекції IP, є взаємопов'язаними. Основою їх розв’язання найчастіше $є$ концептуалізація предметної галузі колекції. 
Для формування колекцій HEIP можуть використовуватися всілякі джерела: періодичні видання; монографії; видання наукової літератури; наукові звіти; дисертації; а також дані, отримані в результаті досліджень; результати комп'ютерного моделювання та інші вже існуючі колекції.

Наукові колекції IP досить різноманітні. Разом із загальними властивостями, характерними будь-яким колекціям, вони володіють у багатьох випадках i специфічними особливостями. Це зумовлено не лише різноманіттям сфер досліджень й особливостями дослідницької діяльності, але й відмінностями у методології та «технологіях» досліджень у різноманітних галузях науки. Звідси, у свою чергу, виникає потреба в широкому спектрі інформаційних технологій для створення колекцій ЕІР наукових ЕБ.

3 функціональної точки зору, колекції НЕІР поділяються на інформаційні дані та метадані (метаінформацію). Ресурси першого роду представляють відомості, що цікавлять користувачів із предметної галузі цієї колекції. У свою чергу метадані колекції характеризують властивості IP, які їй належать, і властивості самої колекції в цілому. За матеріалами Вікіпедії [5] у загальному випадку метадані - це:

- інформація про дані, або ж - це інформація про інформацію;

- $\quad$ структуровані дані, що є характеристиками описуваних об’єктів для цілей їх ідентифікації, пошуку, оцінювання, управління ними;

- $\quad$ набір допустимих структурованих описів, які доступні в явному вигляді і призначення яких допомогти знайти об'єкт, дані чи ресурс;

- дані із загальнішої формальної системи, що описує задану систему.

Але такий поділ IP є досить умовним, тому що IP, які є метаданими відносно до деяких інших EIP колекції чи колекції в цілому, у деяких випадках (коли предметна галузь розглядається користувачем на метарівні) мають значення даних. Очевидно, що наявність метаописів HЕIP значно спрощує процеси створення і модернізації колекцій. Разом із цим, наявність у фонді ЕБ електронних IP поряд 3 їхніми метаописами сприяє підвищенню адекватності IP, знайдених під час пошуку, i вимогам пошуку. Проте технологічність побудови та використання метаописів значною мірою визначається засобами, що застосовувались для створення їх [2].

Метадані можна класифікувати [5] : 
- $\quad$ за вмістом. Метадані можуть або описувати сам ресурс (наприклад, назва і розмір файлу), або вміст ресурсу (наприклад, короткий зміст);

- $\quad$ за відношенням до ресурсу в цілому. Метадані можуть відноситися до ресурсу в цілому або до його частин. Наприклад, «Тіtle» (назва фільму) відноситься до фільму в цілому, а «Scene description» (опис епізоду фільму);

- $\quad$ за можливістю логічного висновку.

\section{Формат метаданих}

Метаданими на практиці, зазвичай, називають дані, представлені відповідно до одного з форматів метаданих [5]. Формат метаданих - $є$ стандарт, призначений для формального опису деякої категорії ресурсів (об'єктів, даних тощо.). Такий стандарт, зазвичай, включає набір полів (атрибутів, властивостей, елементів метаданих), що дозволяють характеризувати даний об'єкт. Наприклад, формат MARC дозволяє описувати сотні характеристик кожного з видів ЕIP (підручники, книги, енциклопедії та ін.), містить поля для опису назви, автора, тематики і безлічі інших характеристик.

Широкого розповсюдження для ЕБ набув стандарт метаданих DCMI (Dublin Core Metadata Initiative - Ініціатива Дублінського ядра метаданих) [6]. Свою популярність для опису електронних IP наукових фондів ЕБ цей стандарт має 3 огляду на простоту його застосування і надання можливості побудови метаописів необхідної повноти [2].

Стандарт містить 15 метаданих 3 відповідними множинами кваліфікаційних описів і пропонує правила опису загальних характеристик ЕIP, що висвітлює вміст pecypcy (Title - Назва, Subject - Предмет, Description - Опис, Туре - Тип, Source - Джерело, Relation - Відношення), інтелектуальну власність (Creator - Автор, Publisher - Видавець, Contributor - Співавтор, Rights management - Права, Coverage - Охоплення) і його стан (Date - Дата, Format - Формат, Identifier Ідентифікатор, Language - Мова).

Слід враховувати, що під час створення масивів ЕIP необхідно дотримуватися світових стандартів опису електронних даних: Dublin Core, UNIMARC, RUSMARC, UKRMARC, USMARC, ONIX i T. ін., що дозволить у першу чергу запобігти дублювання інформаційних носіїв у колекції безпосередньо ЕБ, яку формуєте, та забезпечить їі потенційну інтеграцію у масштабніші проекти. 
Окремі функції метаданих колекцій i ïx зміст можуть значно розрізнятися залежно від характеру ЕБ та конкретної колекції. Проте в будь-якому разі метадані повинні визначати склад колекції, забезпечувати коректну інтерпретацію та обробку представлених у ній інформаційних ресурсів механізмами ЕБ. У зв'язку з цим вони повинні описувати критерії належності HEIP до даної колекції (для неявно заданих колекцій), структурні властивості HЕIP (типи, зв'язки), формати їх представлення, місце розміщення, обмеження цілісності, обмеженням управління доступу і тому подібне. Також метадані можуть описувати i семантичні властивості НЕIP, наприклад, вміст ресурсів, відомості про їх генезис, авторів, контексти вживання, про класифікаційну систему колекції і схему присвоєння імен НЕIP. Склад метаданих цієї групи істотно залежить від генезису i природи HEIP колекції. Для ресурсів експериментальних даних, метадані повинні описувати вигляд експерименту, характеристики використовуваних приладів, умови і час проведення експерименту, а також, можливо, математичну модель досліджуваного феномену.

Вибір того або іншого підходу підтримки метаданих, методів їх подання, а також обміну метаданими між різними інструментальними засобами - завдання розробника колекції HEIP, i вирішення іiі має бути погоджене 3 характером технологій, які використовуються під час створення і використання даної колекції на стадії проектування і створення наукової ЕБ.

Важливе значення в розробці колекцій мають також технології управління метаданими. Напрацювання в цьому напрямку привели до включення у версію мови HTML 2.0 простих засобів, що дозволяють вбудовувати метадані в HTML-документи [1]. Описи семантики наборів таких засобів для різних предметних областей, які називаються схемами, мають бути представлені на яких-небудь WWW-серверах. Атрибути що входять до набору, називаються елементами відповідної схеми. У синтаксис мови було введено новий тег META з двома атрибутами - NAME i CONTENT. Перший із них задає ім'я елементу схеми, кваліфіковане ідентифікатором схеми, а другий — його значення. Теги МЕТА можуть повторюватися довільне число разів у HTML-документі, дозволяючи тим самим асоціювати 3 ним необхідну кількість атрибутів метаданих. Посилання на місце розташування схеми у WWW (URL) разом із присвоєним їй ідентифікатором, вказується в тегу LINK. Отже, 
з'явилася можливість включати в HTML-документи структуровані метадані, що характеризують їхній зміст, наприклад, значення елементів Дублінського ядра [6].

Згодом вказані засоби мови HTML отримали подальший розвиток у версії HTML 4.0, під впливом підготовленого W3C (World Wide Web Consortium) засобів опису семантики документів у середовищі Web, заснованих на новій мові розмітки XML. Зокрема, для тегу META були введені додаткові атрибути LANG i SCHEMA, які дозволяють задати, відповідно, мову представлення значення елементу метаданих у цьому тегу й уточнюючий контекст для адекватної його інтерпретації. З'явився також новий атрибут профілю документа PROFILE в тегу HEAD заголовку, що містить посилання (URL) на ресурс у Web, де визначаються елементи метаданих даного документа та їхні значення. Формат вмісту профілю на мові не регламентований.

Водночас метадані, представлені засобами RDF, можуть використовуватися для ефективнішого пошуку ресурсів пошуковими машинами WWW, в електронних бібліотеках, в описах колекцій сторінок Web, складових деяких віртуальних документів, для представлення змісту IP з конкретних предметних галузей, а також для підтримки різних інших Web-сторінок, що потребують семантичної інформації про ресурси. У завдання RDF [6] не входила стандартизація яких-небудь наборів семантичних властивостей і вони можуть бути різними для різних застосувань. Для деяких предметних галузей уже існують такого роду стандарти. Так, наприклад, для опису семантики електронних текстових документів у середовищі Web запропонований набір властивостей названий Дублінським ядром. У стандарті RDF показано, як Дублінське ядро може бути виражене засобами RDF Schema.

Вибираючи формати файлів, необхідно орієнтуватися на стандарти, що підтримуються засобами тих ОС, які нині використовуються в інформаційних установах i розвиток яких можна спрогнозувати в подальшому. Так, можна прогнозувати довгий життєвий цикл форматів XML, HTML, а також pdf, tiff (текстова інформація), avi, mpeg (мультимедія), jpeg (графічна інформація). Компетентний підхід до вибору форматів зберігання інформації дозволить максимально запобігти в майбутньому проблем підтримки, використання і відображення даних новими програмними засобами. 
Під час формування інфраструктури ЕБ НАПН України, створення HEIP для забезпечення всіх форм навчання та проведення наукової діяльності стає стратегічним напрямком розвитку наукових установ і НАПН України. На підставі аналізу діяльності наукових інститутів та центрів НАПНУ за останні роки, пропонується схема формування колекцій НЕIP наукової ЕБ та метаописів HЕIP (рис. $1)$. 


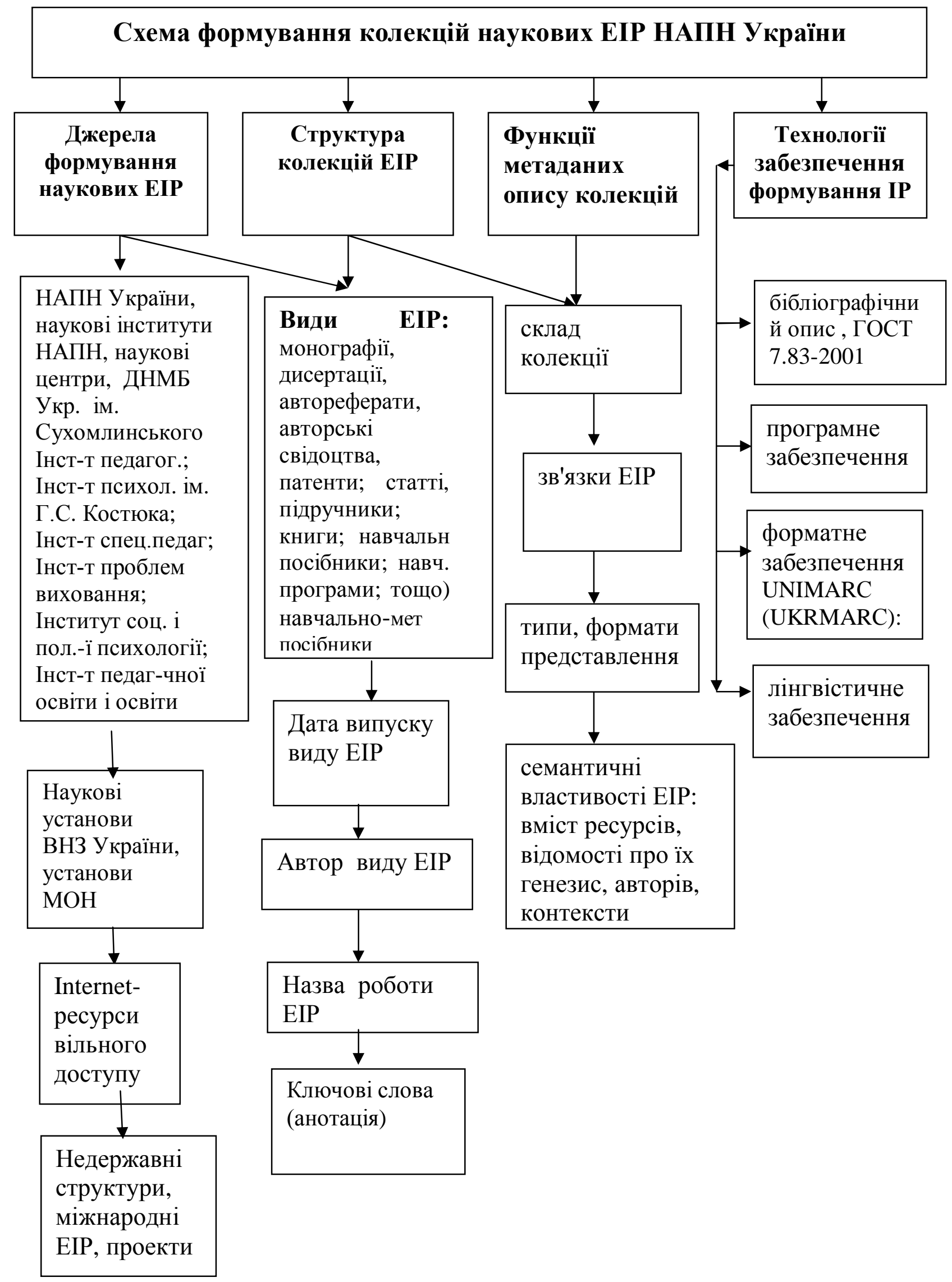

Puc. 1 
Метаописи (створення метаданих HEIP ) складаються з таких етапів [7]:

- $\quad$ планування процесів метаописів;

- процеси, пов'язані із споживачами;

- проектування і розробка метаданих;

- експлуатація — перевірка роботи та достовірності метаданих;

- $\quad$ моніторинг.

На етапі планування циклу метаописів інформаційного науково-освітнього ресурсу мають бути визначені і задокументовані потреби у процесах, організаційних заходах, документах, ресурсах, що забезпечують своєчасне створення та ефективне використання метаописів. На цьому етапі має бути врахована специфіка інформаційного науково-освітнього ресурсу і середовища його поширення.

На етапі проектування і розробки метаописів організація-розробник повинна документувати i, якщо це необхідно, здійснювати такі процеси щодо метаописів:

- аналіз вимог до метаописів і аналіз вимог до засобів їх створення;

- $\quad$ проектування архітектури метаописів ;

- $\quad$ технічне проектування метаописів;

- $\quad$ програмування і тестування метаописів;

- кваліфікаційні випробування метаописів;

- $\quad$ уведення метаописів у практичне використання.

У робочому процесі метадані повинні експлуатуватися в установленому для них експлуатаційному середовищі відповідно до встановлених вимог. Організаціявласник інформаційного ресурсу повинна планувати і здійснювати експлуатаційні випробування й актуальну підтримку метаописів. Для цього організація-власник повинна розробляти, планувати і періодично здійснювати процедуру моніторингу метаописів.

Розробники ЕБ мають можливість вибору типів інформаційних ресурсів, організації і способів представлення колекцій ЕІР, вибору форматів метаданих іа технології управління метаданими, але вибір істотно залежать від програмного забезпечення й інформаційних технологій, які використовуються в проектуванні та побудові ЕБ. 
Висновки. Наведені результати аналітичного огляду призначаються користувачам та розробникам ЕБ. На етапі проектування та впровадження наукової ЕБ НАПН України можуть бути використані результати дослідження, а саме: схема формування колекцій наукових ЕIP НАПН України (джерела НЕIP, структура та види HEIP колекції); етапи проектування і розробки метаописів і використання стандарту Дублінське ядро для опису НЕIP - створення метаописів.

Перспективами подальшого розвитку робіт зі створення наукових електронних бібліотек $є$ необхідність ефективної кооперації всіх установ, які займаються створенням i поширенням HEIP - академічних i наукових установ, ВНЗ, інформаційних центрів, бібліотек, архівів - у галузі створення інформаційних систем, призначених для збереження та надання вільного доступу до наукової інформації і наукових електронних бібліотек. Економічно доцільною є організація інформаційної взаємодії всіх суб'єктів інформаційної інфраструктури країни (ученихавторів наукових публікацій, видавництв науково-дослідних і навчальних установ, бібліотек i iнформаційних центрів) для спільного створення i використання електронних інформаційних ресурсів [8]. Такий шлях дозволить запобігти дублювання робіт 3 опрацювання інформаційних джерел, розширити спектр опрацьовуваної інформації, зекономити всі види виробничих ресурсів, забезпечить перетворення IP в електронні інформаційні продукти 3 високими показниками ефективності - оперативності надання інформаційних послуг та повноти охоплення інформаційних матеріалів.

\section{Список використаних джерел}

1. Когаловський М. П. Наукові колекції інформаційних ресурсів в Електронних бібліотеках / М. П. Когаловський - Інститут проблем ринку РАН., праці Першої Всеросійської наукової конференції «Електронні бібліотеки: перспективні методи i технології, колекції електронних ресурсів». - С-П., 1999: [Електронний ресурс]. — Режим доступу: http://www.cemi.rssi.ru/mei/articles/dlib.htm\#НАУЧНЫЕ. — Заголовок 3 екрана.

2. Спірін О. М., Саух В. М., Резніченко В. А., Новищкий А. В. Проектування системи електронних бібліотек наукових i навчальних закладів АПН України. /О. М. Спірін, В. М. Саух, В. А. Резніченко, О. В. Новицький. - ISSN 2076-8184. Інформаційні технології і засоби навчання. - К., 2009, № 6: [Електронний ресурс]. - 
Режим доступу: http://www.nbuv.gov.ua/e-journals/ITZN/em14/content/09somuoa.htm. — Заголовок з екрана.

3. Влащенко Л. Технологія створення колекції повнотекстових електронних видань у бібліотеках //Бібліотечний форум України. — 2005. — №4. - С. 26-30.

4. Когаловский наукометрические показатели и показатели качества метаданных системы Соционет /Труды Девятой Всероссийской конференции «Электронные библиотеки: перспективные методы и технологии, электронные коллекции». - RCDL-2007, г. Переславль-Залесский, Россия, 15-18 октября 2007 г. - С. 45-54.

5. Метадані, матеріал з Вікіпедії [Електронний ресурс]. - Режим доступу: http://ru.wikipedia.org/wiki/\%D0\%9C\%D0\%B5\%D1\%82\%D0\%B0\%D0\%B4\%D0\%B0\%D 0\%BD\%D0\%BD\%D1\%8B\%D0\%B5. - Заголовок з екрана.

6. Dublin Core Metadata Initiative. DCMI GLOSSARY. [Електронний ресурс]. Режим доступу: http://dublincore.org/documents/userguide/glossary.shtml.

7. Тіхонов А. Н. Стандарт - Метадані інформаційних освітніх ресурсів для Інтернет-каталогів./ А. Н. Тіхонов. Державний науково-дослідний інститут інформаційних технологій і телекомунікацій «Інформіка», Міністерство освіти $\mathrm{i}$ науки Російської Федерації, 2004. [Електронний ресурс]. — Режим доступу: http://www.imsglobal.org/metadata. - Заголовок з екрана.

8. Баркова О. В. Напрями розвитку технологій формування інформаційних ресурсів електронних бібліотек в Україні /О.В.Баркова. Національна бібліотека України ім. В. І. Вернадського, Київ. [Електронний ресурс]. — Режим доступу: http://www.nbuv.gov.ua/articles/2002/02bovelu.htm. - Заголовок з екрана.

\section{КОЛЛЕКЦИИ ЭЛЕКТРОННЫХ ИНФОРМАЦИОННЫХ РЕСУРСОВ И ИХ МЕТАОПИСАНИЯ КАК КОМПОНЕНТЫ НАУЧНЫХ ЭЛЕКТРОННЫХ БИБЛИОТЕК}

Савченко 3. В.

Аннотация

В статье представлены результаты исследования составляющих научных электронных библиотек, основными из которых являются коллекции научных электронных информационных ресурсов. Приведены важнейшие специфические 
особенности коллекций научных информационных ресурсов, источники их формирования, структура коллекций, методы их систематизации, технологии создания, обеспечения поддержки и использования научных коллекций; роль и функции метаданных в коллекциях и технологии управления метаданными. На этапе проектирования и внедрения научных электронных библиотек могут быть использованы результаты исследования, приведенные в статье, а именно: схема формирования коллекций научных информационных ресурсов; этапы проектирования и разработки метаописаний, а так же использование стандарта Дублинское ядро, создание метаописаний.

Ключевые слова: коллекции электронных информационных ресурсов, электронная библиотека, метаданные, метаописания.

\section{COLLECTIONS OF ELECTRONIC INFORMATION RESOURCES AND THEIR METADESCRIPTIONS AS COMPONENTS OF SCIENTIFIC ELECTRONIC LIBRARY}

Savchenko Z.

\section{Resume}

The article presents the results of scientific research components of digital libraries, the main ones being the collection of electronic scientific information resources. An important specific characteristics of collections of scientific information resources, resources of their formation, structure collections, methods of their organization, technology creation, support and use of scientific collections, the role and function of metadata in collections and metadata management technology are represented. On the stage of planning and introduction of scientific e-libraries there can be used results of researches presented in the article, namely: chart of forming of collections of scientific informative resources; stages of planning and development of metadescriptions, and similarly the use of standard the Dublin kernel, creation of metadescriptions.

Keywords: collection of electronic information resources, digital library, metadata, metadescriptions. 